Atlas Journal of Biology 2017, pp. 402-406

\title{
The Procedure of Seed Potato Certification in Morocco
}

\author{
Fadoua Eljai ${ }^{1}$, Meryem Slamini ${ }^{2}$, Ibtissam Mzabri2 ${ }^{2}$, Ibtihal Bekkouch ${ }^{2}$, Nour Eddine Kouddane ${ }^{2}$, \\ and Abdelbasset Berrichi ${ }^{2}$
}

${ }^{1}$ Laboratory of Management and Development of Companies and Organizations, Superior School of Technology, University Mohammed First, P.O. Box 473, Oujda 60000, Morocco; ${ }^{2}$ Biology of Plants and Microorganisms Laboratory, Faculty of Sciences, P.O. Box 717, Oujda 60000, Morocco

Received: June 16, 2017 / Accepted: July 4, 2017

\begin{abstract}
The potato (Solanum tuberosum L.) is a geophyte of the Solanaceae family and it represents the first crops in Morocco. Thanks to its high nutritional value, the seed requirements attain around $160000 \mathrm{~T}$ of which $70 \%$ originate from the previous production, which is the reason behind the limitation of the market's development. Considering the importance of the certified seeds, Morocco has signed a Program Contract to develop this sector. The production of certified potato seedling is a whole pro-cess that begins with the selection of plants and goes on until the marketing of the product where the producer should absolutely respect the cultivation processes and hygiene standards. The establish-ment and the insurance of compliance with these standards is carried out by the National Office of Sanitary Safety and Food Supplies (ONSSA). The purpose of the following work is to summarize and represent briefly the certification standards of potato seeds in Morocco.
\end{abstract}

Keywords: Seed, potato, ONSSA, certification, standards, Morocco.

*Corresponding author: btissammzabri@gmail.com

\section{Introduction}

The seed is the first key element in plant production. The use of quality seed represents one of the investments with the highest multiplier effect of the entire agricultural economy. Beside the im-portance of seeds in crop production, the seed trade provides many jobs in rural areas where they generate significant revenues globally. The Global Seed Market was estimated at 42 billion USD in 2011 (ISF, 2011). This estimation attracted the attention of scientists and required scientific research, investment and the use of advanced technology in the field of seed production. Yet, experience shows that the seed industry is failing to develop satisfactorily due to the lack of appropriate legis-lation. Concerning the legal and economic globalization, the seed sector has, in the past years, had a multitude of legal rules with the aim of strengthening the food quality and safety through the har-monization of the national legislation on seed trade. A number of international organizations, con-ventions and treaties have been set up to deal with the regulation of the seed trade. Since the be-ginning of the 1970's, the seed sector in Morocco has known a sustained growth thanks to a juridical arsenal for the seed industry, which has been complemented by the promulgation in 1997 of Law 9-94 on the protection of plant varieties which entered into force on 28 October
ATLOS Publishing, LP

This is an Open Access article distributed under the terms of the Creative Commons Attribution License (http://creativecommons.org/licenses/by/3.0/), which permits unrestricted use, distribution, and reproduction in any medium, provided the original work is properly cited. 
2002 (ONSSA, 2015). These national regulations are added to the global organizations of which Moroc-co is a member, such as the Organization for Economic Co-operation and Development (OECD), The International Seed Testing Association (ISTA), The International Union for the protection of New Va-rieties of Plants (UPOV), the International Seed Federation (ISF) and the UN Food and Agriculture Organization (FAO). These different international organizations constitute a regulatory framework that monitors the interests of all breeders, producers and consumers. The potato (Solanum tuberosum L.) is a geophyte of the Solanaceae family. Recently, it has become a leading product in the seed in-dustry thanks to the cultural and culinary revolution that created the fast food chains. In Morocco, potato cultivation tops on the market garden with an area of 60000 ha, accounting for $23 \%$ of the total area of vegetable crops and an annual output of 1.5 million tons with average yields between 17 and $18 \mathrm{~T} /$ $\mathrm{Ha}$ (Skiredj.,2007). Considering the high demand for potatoes, it is practically culti-vated in all regions of Morocco with four types of cultivation, namely early cultivation; where plant-ing occurs in September-December, seasonal cultivation in January -February, the culture of back-season in August and the culture of mountain in May (Chibane, 1999). The global seed demand is around 160 000 tons, including 20000 tons for early-growing crops. 30\% of these needs are cov-ered by imports and $70 \%$ by common plants taken from previous productions. Given the importance of Seed Certification, Morocco signed a Program Contract in 2009 to develop the sector of certified potato seed production, which will cover $30 \%$ of certified seed needs in the near future (2020) instead of the current coverage that represents only $2 \%$ (AISSI, $2014)$.

The following study aims to establish the certification process for potato seeds in Morocco by re-ferring to the standards established by the National Office for Food Safety (ONSSA, 2015).

\section{The Stages of Potato Seed Certification}

The process of potato seed certification requires several stages and several generations of multiplication under tight control throughout the production chain (Figure 1).

\section{The Selection of High-Performing Plants}

This selection constitutes the first link of this chain, where we distinguish two techniques:

I. Mass selection: this is the oldest empirical method. It consists of selecting the plants that appear to be the most interesting in a population and using their seeds as seeds for the next crop (Burg, 2004).

II. Selection by hybridization: It consists in crossing two species or two varieties with each other, which gives plants new characteristics. This technique makes use of a long varietal selection (Bouharmont, 1995).

III. Entry in the Official Catalogue

IV. When a new variety is created, its breeder requests it to be registered in the official catalogue. It must be submit- ted to the so-called DHS test: distinction, homogeneity and stability and, on the other hand, to the VAT test: agronomic and technological value which is based on the assessment of the agronomic and technological performance of the candidate variety in relation to the reference varieties that are already widely cultivat-ed in the territory.

In order to officially register in the catalogue, there are three major steps to be followed: (I) The application for registration should be submitted by the breeder to ONSSA, this application has to be accompanied by samples of $300 \mathrm{~kg}$ of seedlings for varieties whose seed may be marketed in Morocco or abroad as well as $50 \mathrm{~kg}$ for varieties whose seeds may be propagated in Morocco for export, (II) A receipt for payment of the registration fee paid by the applicant to ONSSA, and (III) A Certificate signed by the breeder and / or the holder of the variety authorizing the filing of the ap-plication in the event that the applicant is not the breeder. After registration in the official catalog, the seed of the registered variety must undergo several generations of propagation before reaching the farmer.

\section{Stages of Propagation}

During this phase, the potato seed takes the following names:

I. Starting plants: corresponding to the original material of the authentic variety, it must be free mainly from degenerative diseases (virus $Y$, virus $X$, virus $A, \ldots$ ) and quarantine pests and diseases in accordance with current phytosanitary legislation.

II. Pre-base plants: seedlings that are usually multiplied from the original material; the number of field generations should not exceed four.

III. Basic seedlings (Elite and Super Elite classes): the basic plants come from the multiplication of the pre-base or base plants, provided that the number of basic seedlings must not exceed four and that the number of cumulative pre-base and base generations does not exceed seven.

The Super Elite (SE) class corresponds either to the harvest from pre-basic or basic plants, and the number of generation of pre-basic seedlings in the field and basic seedlings is limited to six. For the Elite class $(E)$, the crop is either from pre-basic plants or from basic plants and the number of genera-tions of pre-basic plants in the field and basic plants is limited to seven.

IV. Certified plants (Classes A and B): certified plants are originated from the propagation of pre-basic or basic plants, and may also be produced from a first generation of certified plants. De-pending on the level of quality compared to the standards, certified plants can be classified in class A or B.

In order to produce different categories of certified potato material, the multiplier must have the following: (1) an authentic genetic material free from disease and nematodes, (2) accessible land with a min-imum area of $1 / 2$ hectare $(0.5 \mathrm{ha})$ for basic seedlings and one hectare ( $1 \mathrm{ha}$ ) for certified seedlings 

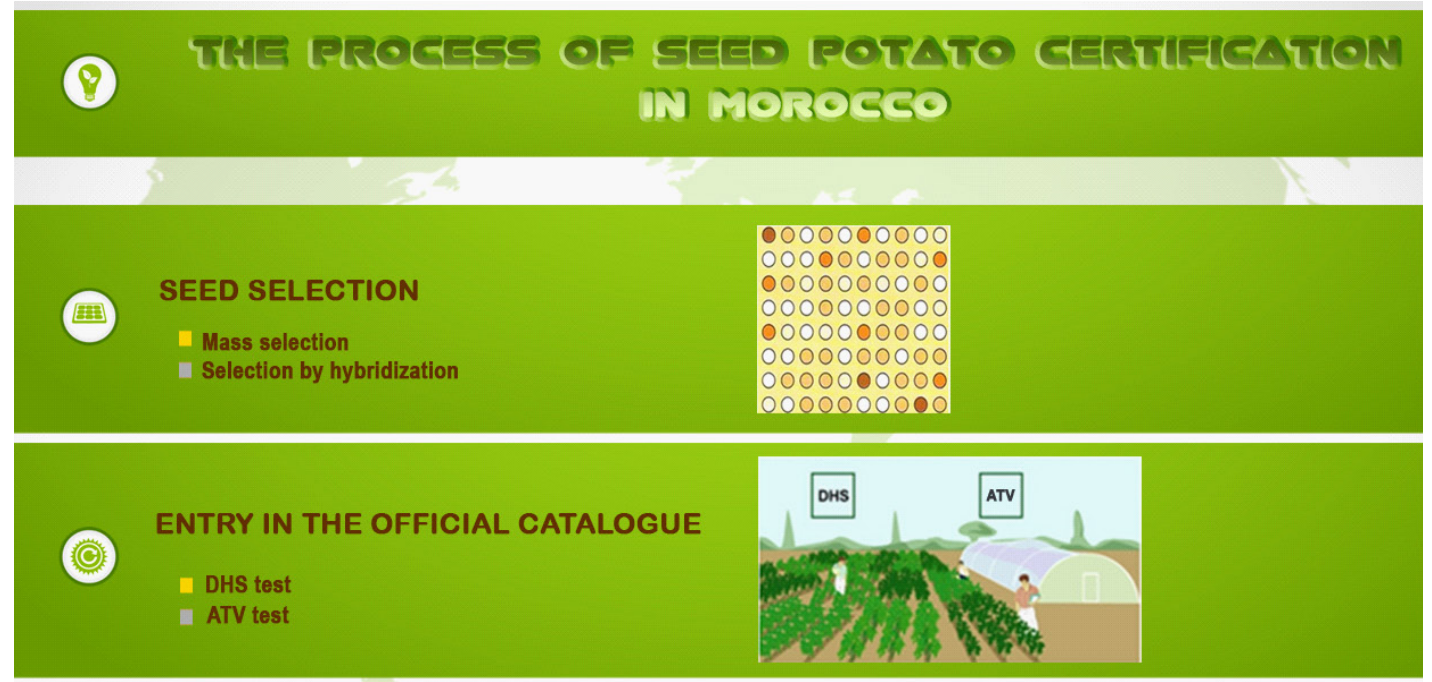

- STAGE OF PROPAGATION Starting plants

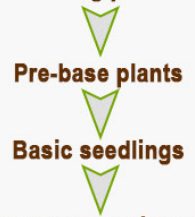

Elite and Super Elite classes<smiles>C1C2CC1C2</smiles>

Certified plants (Classes A and B)

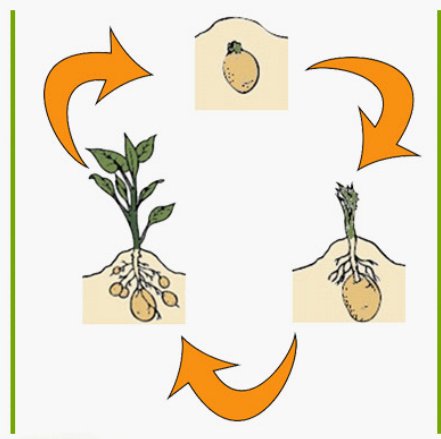

the multiplier must have (1) an authentic genetic material free from disease and nematodes, (2) accessible land with a minimum area of $1 / 2$ hectare $(0.5 \mathrm{ha})$ for basic seedlings and one hectare ( $1 \mathrm{ha}$ ) for certified seedlings and an installation that meets the production standards for potatoes.

\section{- CONTROL STAGE}

Field control

Plants shall be subject to at least

3 periodic surveys.

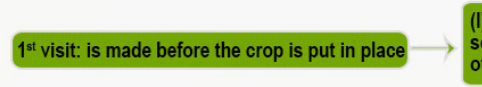

\section{verifying the origin of the plants (III) sampling soil for nematological tests (III) Verification} of the isolation and rotation,

光

Laboratory control

Viral, nematological, bacteriological and

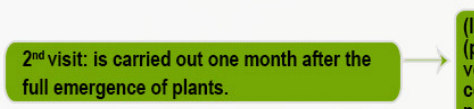

(I) examine the general conditions of the plots

presence of weeds, abnormalities of the vegetative apparatus) (III) assess the rate of
contamination (III) check the quality of the purification.

mycological analyzes

苗 Control during storage

Check the storage conditions (temperature, humidity, isolation of varieties), the hygiene

conditions and the damage that can be caused by the diseases Post-harvest.

요

Conditioning control

(I) sorting of tubers with abnormalities, (II) tuber drying,

(III) sizing of the tubers

(IV) treatment of the tubers against crop plant diseases,

(V) packaging tubers that will be sealed afterwards.

Marketing control

Verification: origin, size, weight of the bags, conditions and shelf life and the health status of the tubers.

야으

Stage of certification and labeling A certified seed bag should carry two labels: one on the bag and the other in the bag, their colors shall vary according to the type of seed and they must bear all the necessary information on the lot in question (lot number, variety, class, caliber, treatment product ...

Figure 1. Schematic of seed potato certification as a propagation material. 
Table 1. Standards for Minimum Insulation Distances.

\begin{tabular}{lcccc}
\hline Category & Prebase & $\begin{array}{c}\text { Base SE } \\
\text { and E }\end{array}$ & $\begin{array}{c}\text { Certified A } \\
\text { and B }\end{array}$ & $\begin{array}{c}\text { Cultivation of solanaceous, } \\
\text { cruciferous and stone fruit trees }\end{array}$ \\
\hline Prebase & 1 rang vide & $20 \mathrm{~m}$ & $40 \mathrm{~m}$ & $500 \mathrm{~m}$ \\
Base SE and E & $20 \mathrm{~m}$ & 1 rang vide & $20 \mathrm{~m}$ & $300 \mathrm{~m}$ \\
Certified A and B & $40 \mathrm{~m}$ & $20 \mathrm{~m}$ & 1 empty row & $200 \mathrm{~m}$ \\
\hline
\end{tabular}

Table 2. Deadline for topkilling.

\begin{tabular}{ccccc}
\hline \multirow{2}{*}{ Categories } & \multicolumn{4}{c}{ Classification by date of removal } \\
\cline { 2 - 5 } & At the deadline & $\begin{array}{c}\text { During the first } \\
15 \text { days after the } \\
\text { deadline }\end{array}$ & $\begin{array}{c}\text { between } 16 \text { and } 20 \\
\text { days after the } \\
\text { deadline }\end{array}$ & $\begin{array}{c}\text { More than } 20 \text { days } \\
\text { after the deadline }\end{array}$ \\
\hline Plants de Base & SE & A & B & Refusal \\
- SE & E & A & B & Refusal \\
- E & A & A & B & Refusal \\
Certified plants & B & B & B & Refusal \\
\hline
\end{tabular}

and an installation that meets the production standards for potatoes. The production declaration, 15 days after the installation of the production program, should be addressed to the certification body.

Taking in consideration the importance of control in the certified potato seed production scheme, the certification body exercises control at all stages, namely: Field control, laboratory control, control during storage, control during packaging and control to marketing. In order to do so, an application for inspection must be sent to the certification body, and should be accompanied by (I) receipt of the payment of the inspection fee, (II) a document that indicates the location of the parcels to be con-trolled (III) documents justifying the origin of the plants, (IV) analyses of the soil of the seed multipli-cation plots.

\section{Field Control}

This depends on the type of plant material. For the starting and pre-base material, the breeder or maintainer are the ones responsible for control, while the basic super Elite, Elite and A or $B$ certified seedlings should be subject to at least 3 periodic surveys.

The first visit is made before the crop is put in place and consists of (I) verifying the origin of the plants by checking the labels of the invoices and delivery notes. (II) sampling soil for nematological tests in a representative pattern that takes into account the field's architecture, variability and ag-gregation of nematodes (for a surface area of 0.5 to $1 \mathrm{ha}$, sampling should be between 10 And 50 samples). (III) Verification of the isolation and rotation, the land for production must have at least a three years rotation for the pre-base and base plants and at least two years for the certified plants (Class A and B). Thus, plots must respect the prescribed isolation distances (Table 1) in order to avoid the transmission of degenerative diseases (viral diseases). The second visit is carried out one month after the full lifting. The purpose of this visit is (I) to examine the general conditions of the plots (presence of weeds, abnormalities of the vegetative, apparatus: deformations, foliar discolorations, etc.), (II) To assess the rate of contamination by the pests via the diagnosis of $20 \mathrm{~m} 2(5 \mathrm{~m} * 4 \mathrm{~m})$ bands are chosen according to a well-defined sampling scheme that takes into consideration the size and geometric shape of the production plot (the minimum number of controlled bands is 5), (III) To check the quality of the purification by tearing off the feet of different appearance and not con-forming to the variety, feet suffering from diseases. The third visit is carried out when the varietal characters are visible, it allows (I) the assessment of the rate of contamination by viral, bacterial and plant fungal diseases, (II) the checking of the varietal purity based on the shape of the leaves, the color of the flowers, the coloration of the collar, the ribs and the hair of the leaves, etc., (III) The estima-tion of the yield using the formula: Yield = Stand Weight / Stand X Stand / Ha, (IV) set the date of top killing to be carried out within the timeframe set by ONSSA for seed types and climatic conditions (Table 2). Table 2 shows the standards set for top killing.

\section{Laboratory Control}

After harvest, tubers are examined in the laboratory; the main analyzes which are viral, nematolog-ical, bacteriological and mycological. The sample used for these tests should be presented with a minimum of 220 tubers for basic plants and 110 tubers for certified plants. 


\section{Control During Storage}

Its purpose is to check the storage conditions (temperature, humidity, isolation of varieties), the hy-giene conditions of the storage rooms and the damage that can be caused by the Postharvest dis-eases.

\section{Conditioning Control}

During this phase, the tubers go through several stages, namely (I) sorting of tubers with abnormali-ties, (II) tuber drying, (III) sizing of the tubers depending on the type (round varieties 30-65 mm and 28-55 mm for oblong varieties, (IV) treatment of the tubers against crop plant diseases, $(V)$ packag-ing tubers in new bags of 25 or $50 \mathrm{~kg}$ that will be sealed afterwards.

\section{Marketing Control}

The aim of this step is to verify and control the compliance with the packaging stages mentioned above: origin, size, weight of the bags, conditions and shelf life and the health status of the tubers.

Stage of certification and labeling: During this final stage, the certification body proceeds to the labeling and the sealing of the bags that respect the prescribed stages of production, preservation and packaging. A certified seed bag should carry two labels: one on the bag and the other in the bag, their colors shall vary according to the type of seed and they must bear all the necessary in-formation on the lot in question (lot number, variety, class, caliber, treatment product, etc.).

\section{Conclusion}

The seed potato certification is the culmination of a monitoring process that enables the official ser-vice (ONSSA) to ensure that the submitted seedlings meet the standards established by the inspection body. The use of certified seed is the most efficient means of spreading and disseminating genetic progress, since it ensures high productivity, adaptation to various biotic and abiotic stresses and quality that meets the market requirements.

\section{References}

Aissi N (2014) Le Maroc ne profite pas de sa pomme de terre. [Internet]. Accessed at: http://www.leconomiste.com/article/94744 1-lemaroc-ne-profite-pas-de-sa-pomme-de-terre.

Bouharmont J (1995) Création variétale et amélioration des plantes. Bases physiologiques et agro-nomiques de l'amélioration de la production végétale, Hatier. Paris. Agronomie Moderne 313-337.

ONSSA (2015) Office National de Sécurité Sanitaire et des Produits Alimentaires. Accessed at http://www.onssa.gov.ma/fr/index.php

Burg $H(2004)$ La production des semences à petite échelle. Digigrafi editor. p. 107.

Chibane A (1999) Techniques de Production de la Pomme de Terre au Maroc. Bull Mens Liaison d'Information du PNTTA 52: 1-4.

ISF Statistics (2011) Seed. Accessed at http://www.worldseed.org/resources/seed-statistics.

Skiredj A (2007) Legume fruit Maroc. Accessed at: http://www.legumefruit-maroc.com/pomme-terre.php. 